\title{
Investigation of Nematopsis spp. oocysts in 7 species of bivalves from Chonburi Province, Gulf of Thailand
}

\author{
C. Tuntiwaranuruk ${ }^{1, *}$, K. Chalermwat ${ }^{2}$, E. S. Upatham ${ }^{3}$, M. Kruatrachue ${ }^{4}$, C. Azevedo ${ }^{5}$ \\ ${ }^{1}$ Department of Biology, Faculty of Science, Burapha University, Chonburi 20131, Thailand \\ ${ }^{2}$ Department of Aquatic Science, Faculty of Science, Burapha University, Chonburi 20131, Thailand \\ ${ }^{3}$ Department of Medical Science, Faculty of Science, Burapha University, Chonburi 20131, Thailand \\ ${ }^{4}$ Department of Biology, Faculty of Science, Mahidol University, Rama 6 Road, Payathai, Bangkok 10400, Thailand \\ ${ }^{5}$ Department of Cell Biology, Institute of Biomedical Sciences and Center of Marine and Environmental Research, \\ University of Porto, Lg. A. Salazar 2, 4000 Porto, Portugal
}

\begin{abstract}
This is the first detailed report of Nematopsis spp. in Thai bivalves. A monthly survey was conducted on 7 species of commercial bivalves from Chonburi province, on the eastern seaboard of Thailand, from November 2000 to November 2001 to investigate the prevalence of the apicomplexan parasite Nematopsis Schneider, 1892. Nematopsis spp. sporozoites were found in the cultivated bivalves Arcuatula arcuatula, Anadara granosa and Perna viridis as well as the locally harvested Paphia undulata. They were not found in Donax faba, Meretrix meretrix or Saccostrea cucullata. Using light microscopy, we were able to identiby 4 oocyst morphotypes of the gregarine Nematopsis spp. Prevalence of Nematopsis spp. during the 13 mo sampling period was highest in $A$. arcuatula $(91.8 \% ; \mathrm{n}=110)$ and lowest in A. granosa $(59.2 \% ; \mathrm{n}=130)$. The morphology of the oocysts differed between hosts, with an average $(x \pm \mathrm{SD})$ length/width of $16.28 \pm 0.64 / 12.01 \pm 0.35 \mu \mathrm{m}(\mathrm{n}=$ 50) for A. arcuatula, $16.90 \pm 0.71 / 12.69 \pm 0.33 \mu \mathrm{m}(\mathrm{n}=50)$ for $A$. granosa, $17.61 \pm 0.69 / 12.72 \pm 0.36 \mu \mathrm{m}$ $(\mathrm{n}=50)$ for $P$. viridis, and $11.21 \pm 0.62 / 8.55 \pm 0.52 \mu \mathrm{m}(\mathrm{n}=50)$ for $P$. undulata. Identification of oocysts of these apicomplexan gregarines to species was not attempted. The prevalence of infection in relation to habitat and time of sampling is discussed.
\end{abstract}

KEY WORDS: Nematopsis $\cdot$ Disease $\cdot$ Protozoa $\cdot$ Apicomplexa $\cdot$ Bivalve $\cdot$ Thailand

\section{INTRODUCTION}

Many species of molluscs, especially bivalves, are utilized as food in Thailand. The total production of bivalves from aquaculture ranged from 40613 to 92833 t between 1988 and 1997 (FAO 1999) making Thailand the seventh largest producer of molluscs in aquaculture worldwide. The province of Chonburi, on the eastern seaboard of the inner Gulf of Thailand, is the major mollusc aquaculture area. Species of molluscs cultured in the area include the mytilid mussels Arcuatula arcuatula and Perna viridis, the cockle Anadara granosa and the oyster Saccostrea cucullata. In addition, several other species including the donacid clam Donax faba and the venerid clams Meretrix meretrix and Paphia undulata support a substantial artisanal or capture fishery along the coastline.

The microrganisms that may cause diseases or pathological conditions in Thai commercial bivalves have not been investigated in detail. Many mass mortalities of farmed bivalves have been reported in the Thai public media in recent years, and losses that occur annually to mussel and oyster farms have primarily been attributed to poor environmental conditions, when they may have been caused by disease. A preliminary survey recently found apicomplexan oocysts of the genus Nematopsis in gills of Anadara granosa and Perna viridis, and a more detailed survey 
revealed that the primary parasites in other species of bivalves also comprise the oocyst stages of apicomplexan gregarines of the species Nematopsis. These parasites have been associated with mass mortalities of cockles and clams in Portugal (Azevedo \& Cachola 1992), and thus warrant further investigation.

The objective of this research was to describe the oocysts found in the gills of key commercial bivalve species of the Chonburi Province coastal area. To our knowledge, Nematopsis spp. oocysts have not been previously described from any bivalve in Thai waters.

\section{MATERIALS AND METHODS}

We collected 7 species of commercial bivalves from local farms or harvesting areas in Chonburi province, Thailand (Fig. 1) between November 2000 and November 2001. The sampling area is located along a $12 \mathrm{~km}$ stretch of coastline, with intertidal habitats ranging from extensive mud flats at Bangsai (Stn 1), coarse gravel at Ang-Sila, Klong-Prong and Laem-Tan (Stns 2, 3 and 4, respectively) to the sandy beach at Vonnapha (Stn 5). Offshore subtidal habitats corresponding to these stations generally are made up of coarse sand and mud with shell debris. Each month,

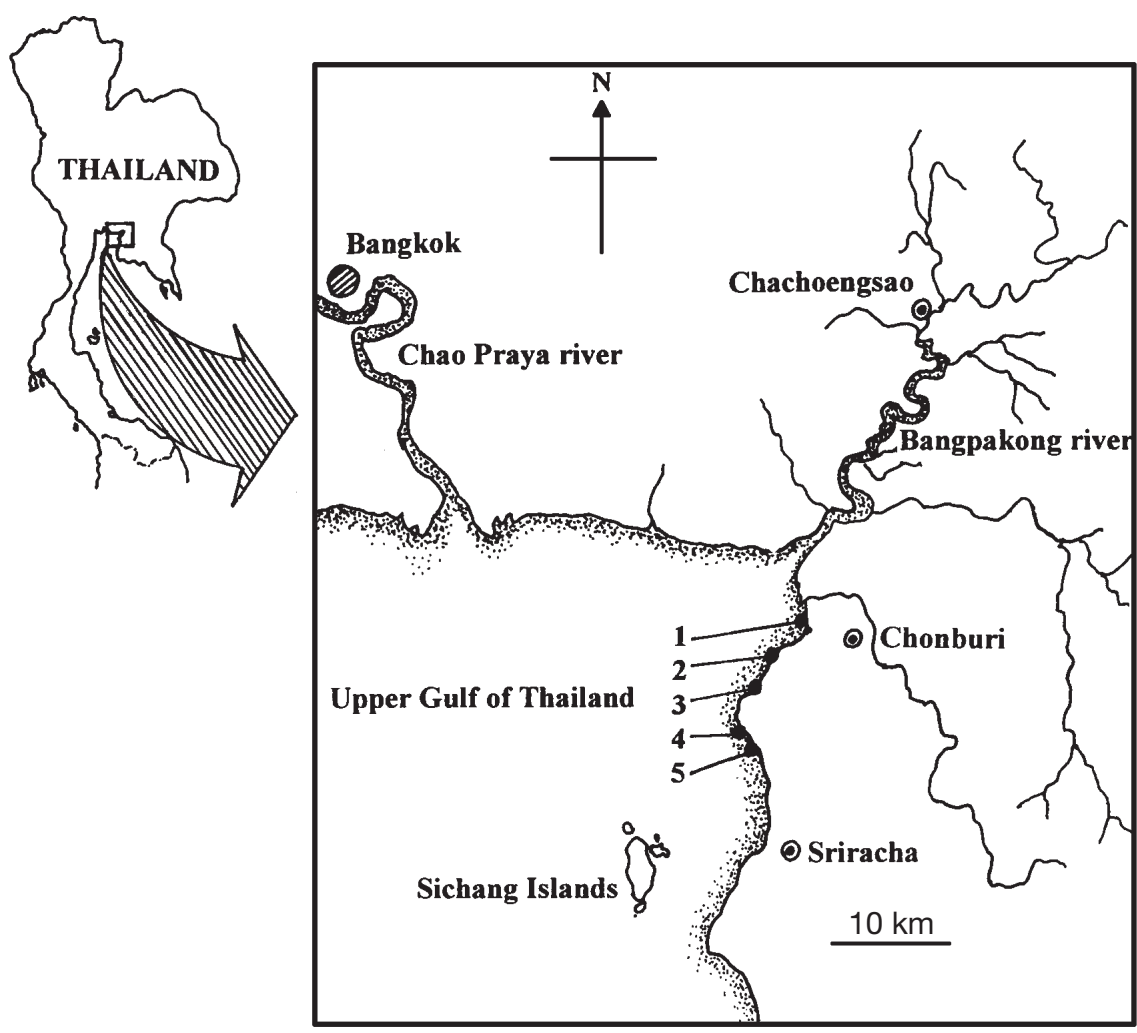

Fig. 1. Area of bivalve farming and fisheries where samples were taken along coastline of Chonburi Province. 1: Bangsai; 2: Ang-Sila; 3: Klong-Prong; 4: Laem-Tan; 5: Vonnapha beach we sampled 10 individuals of the mussel Arcuatula arcuatula and the cockle Anadara granosa from intertidal mud flats (Stn 1). Also on a monthly basis, 10 individuals each of the clams Donax faba and Meretrix meretrix were sampled from sandy beaches at low tide (Stn 5), while 10 green mussels Perna viridis were sampled from offshore mussel farms (Stn 2). The oyster Saccostrea cucullata $(\mathrm{n}=10)$ was sampled from suspended artificial substrates in the intertidal zone (Stn 3). The clam Paphia undulata $(\mathrm{n}=10)$ was sampled from subtidal areas offshore (Stn 4$)$, where sediment is made up of muddy sand. On each monthly sampling occasion, the surface seawater temperature was measured with a thermometer, $\mathrm{pH}$ with a $\mathrm{pH}$ meter, and salinity with a salinity refractometer at all stations. All samples were collected within a period of several hours, and were immediately taken to the laboratory and rapidly processed.

Tissue $\left(4 \mathrm{~mm}^{2}\right)$ from each bivalve species was excised at a mid-ventral position from the inner and outer demibranch on both sides of the bivalve. The tissue was immediately squashed between glass slides and observed under a light microscope by differential interference optics (DIC Nomarski) and photographed. Between 100 and 130 individuals of each bivalve species were examined during the 13 mo study period. In addition, gill-tissue samples of the primary commercial species, Perna viridis, were prepared for histology following standard protocols (Luna 1960). Tissue sections were cut with a rotary microtome at $6 \mu \mathrm{m}$ thickness, stained with eosin and haematoxylin, examined under light microscopy, and photographed.

\section{RESULTS}

The prevalence of oocysts parasitizing the connective tissue of the gill varied between species and sampling months, with high levels of infection being found in Arcuatula arcuatula, Anadara granosa, Perna viridis and Paphia undulata (Table 1). No oocysts were found in Donax faba, Meretrix meretrix or Saccostrea cucullata. In Arcuatula arcuatula, the lowest infection levels occurred in April and May. The lowest levels of infection in Anadara granosa, Perna viridis and Paphia undulata were recorded in May, June and July, respectively. During the study period, surface seawater temperatures ranged from 26.9 to $32.2^{\circ} \mathrm{C}$ (5 station average $=29.72 \pm$ 

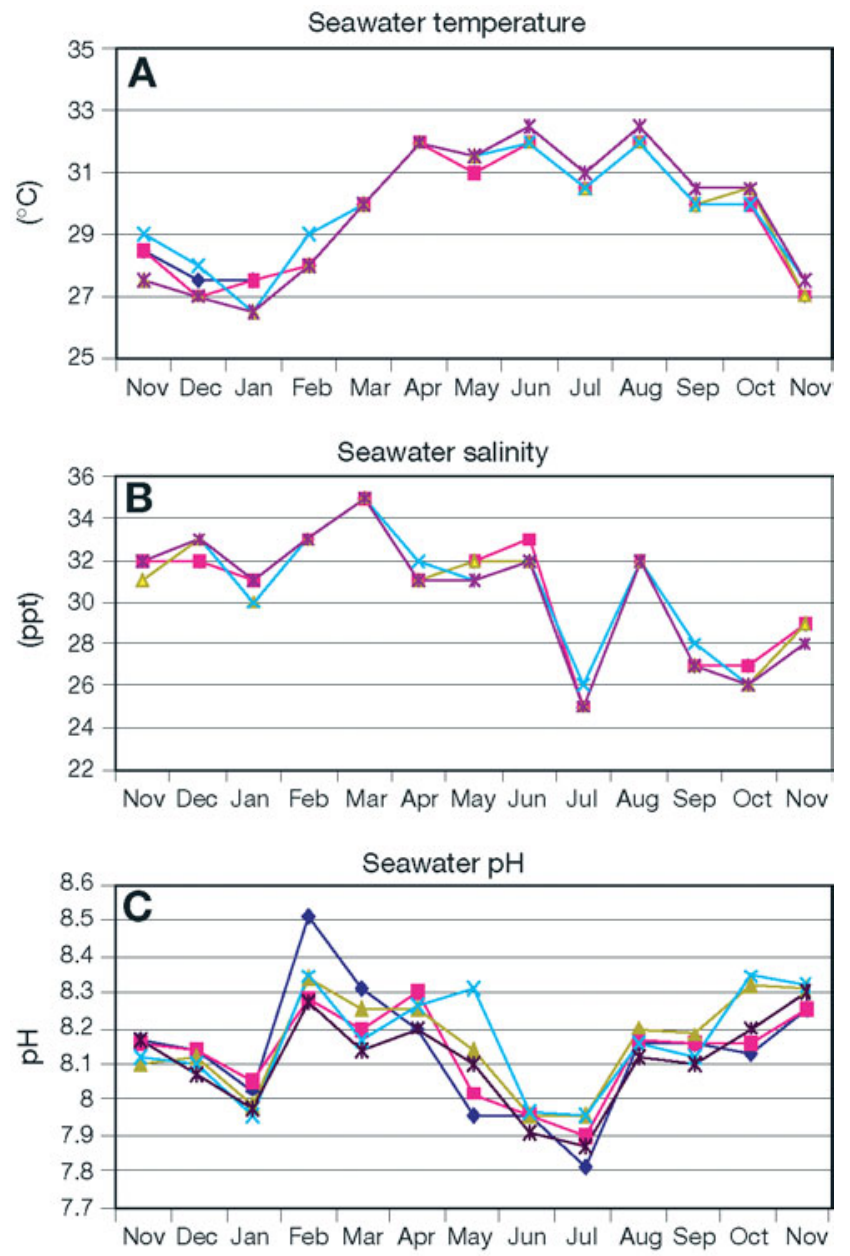

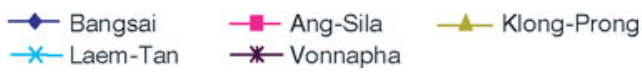

Fig. 2. Monthly seawater (A) temperature, (B) salinity, and (C) $\mathrm{pH}$ at the 5 sampling stations

$1.88^{\circ} \mathrm{C}$ ), salinity from 25.5 to $35.0 \mathrm{ppt}$ ( 5 station average $=30.58 \pm 2.77 \mathrm{ppt}$ ), and $\mathrm{pH}$ from 7.8 to 8.5 (5 station average $=8.14 \pm 0.13$ ) (Fig. 2)

Light micrographs of histological preparations of Perna viridis gills revealed the locations of oocysts within parasitophorus vacuoles and phagocytes

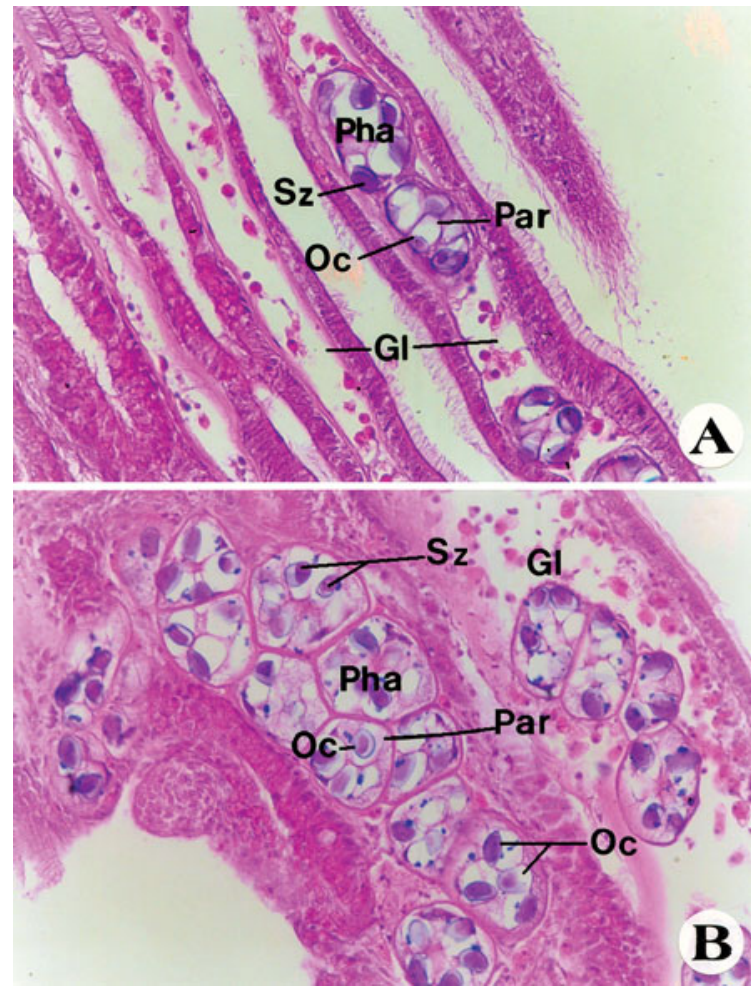

Fig. 3. Nematopsis sp. infecting Perna viridis. Light micrographs (eosin and hematoxylin stain) of (A) moderate and (B) heavy infection, showing phagocytes (Pha) in gill lumina (Gl) and oocysts (Oc) in parasitophorous vacuole (Par); sprozoites $(\mathrm{Sz})$ are clearly visible $(\times 450)$

within the gill lumina (Fig. 3). Lightly infected gills displayed partial occlusion of the lumina, with smallsized phagocytes filled with relatively few oocysts. Each oocyst contained a single, vermiform, uninucleated sporozoite which was clearly visible (Fig. 3A). Heavily infected gills displayed almost complete occlusion of gill lumina, with large phagocytes filled with numerous oocysts (Fig. 3B). Clusters of oocysts were contained within parasitophorous vacuoles varying in size. The prevalence of Nematopsis spp. in the various bivalve species and the average sizes of the oocysts is summarized in Table 1, and the mor-

Table 1. Nematopsis sp. infection in 4 species of bivalves (no. infected per sample of 10 individuals). Bivalves Donax faba and Meretrix meretrix (Stn 5: Vonnapha) and Saccostrea cucullata (Stn 3: Klong-Prong) were never infected (n = 130). nd: no sampling due to severe weather

\begin{tabular}{|c|c|c|c|c|c|c|c|c|c|c|c|c|c|c|c|}
\hline & \multirow{2}{*}{ Stn } & \multicolumn{2}{|c|}{2000} & \multirow[b]{2}{*}{ Jan } & \multirow[b]{2}{*}{ Feb } & \multirow[b]{2}{*}{ Mar } & \multirow[b]{2}{*}{ Apr } & \multirow[b]{2}{*}{ May } & \multirow{2}{*}{$\begin{array}{c}2001 \\
\text { Jun }\end{array}$} & \multirow[b]{2}{*}{ Jul } & \multirow[b]{2}{*}{ Aug } & \multirow[b]{2}{*}{ Sep } & \multirow[b]{2}{*}{ Oct } & \multirow[b]{2}{*}{ Nov } & \multirow{2}{*}{$\begin{array}{c}\text { Mean } \\
(\%)\end{array}$} \\
\hline & & Nov & Dec & & & & & & & & & & & & \\
\hline Arcuatula arcuatula & 1 & 10 & 10 & 10 & nd & nd & 6 & 5 & 10 & 10 & 10 & 10 & 10 & 10 & 91.8 \\
\hline Anadara granosa & 1 & 10 & 8 & 10 & 5 & 4 & 6 & 3 & 3 & 3 & 7 & 5 & 5 & 8 & 59.2 \\
\hline Perna viridis & 2 & 10 & 10 & 10 & 8 & 5 & 5 & 3 & 0 & 2 & 8 & 2 & 5 & 10 & 60.0 \\
\hline Paphia undulata & 4 & 10 & 10 & 10 & nd & nd & nd & 0 & 0 & 3 & 10 & 10 & 8 & 9 & 70.0 \\
\hline
\end{tabular}




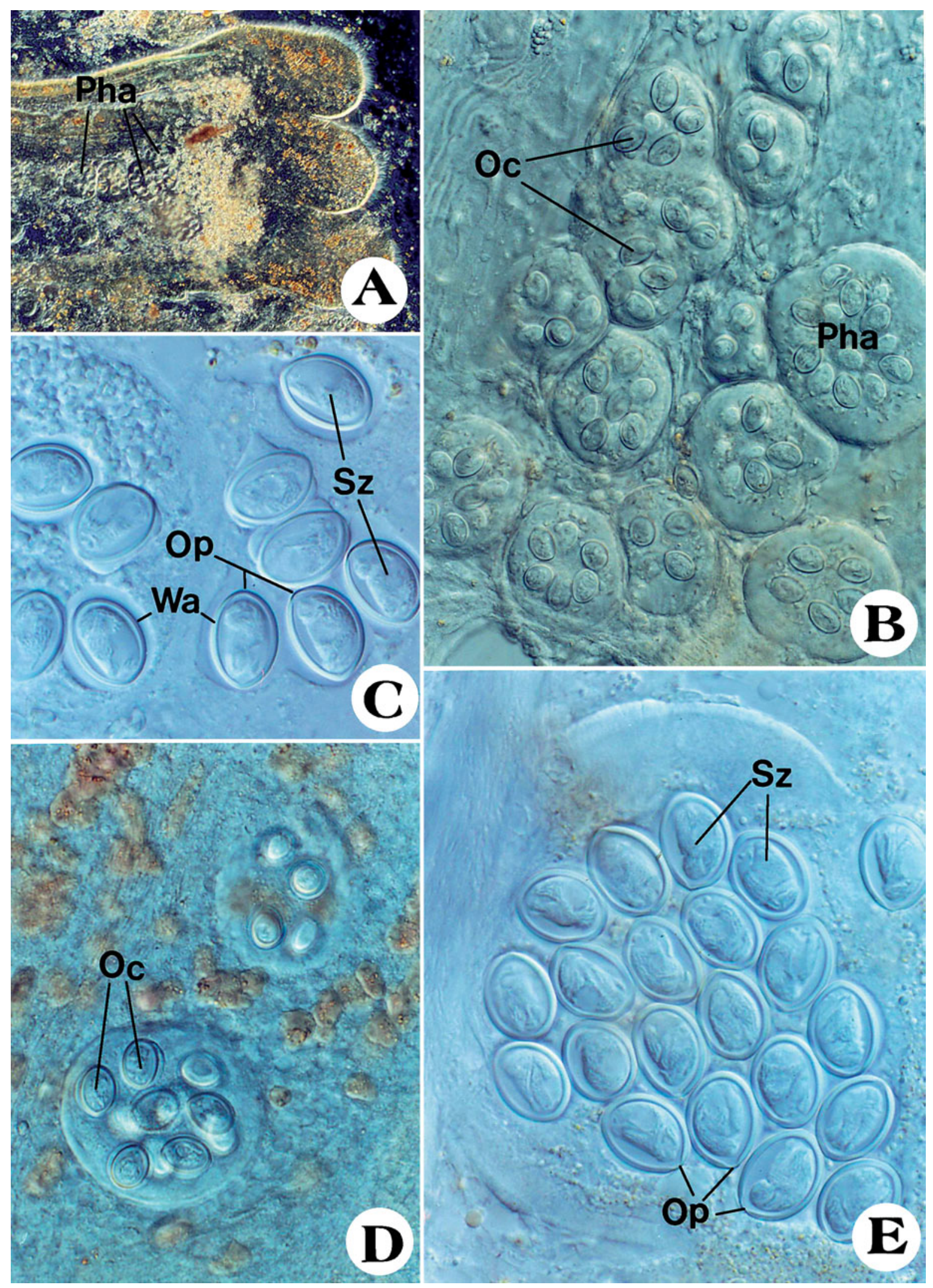



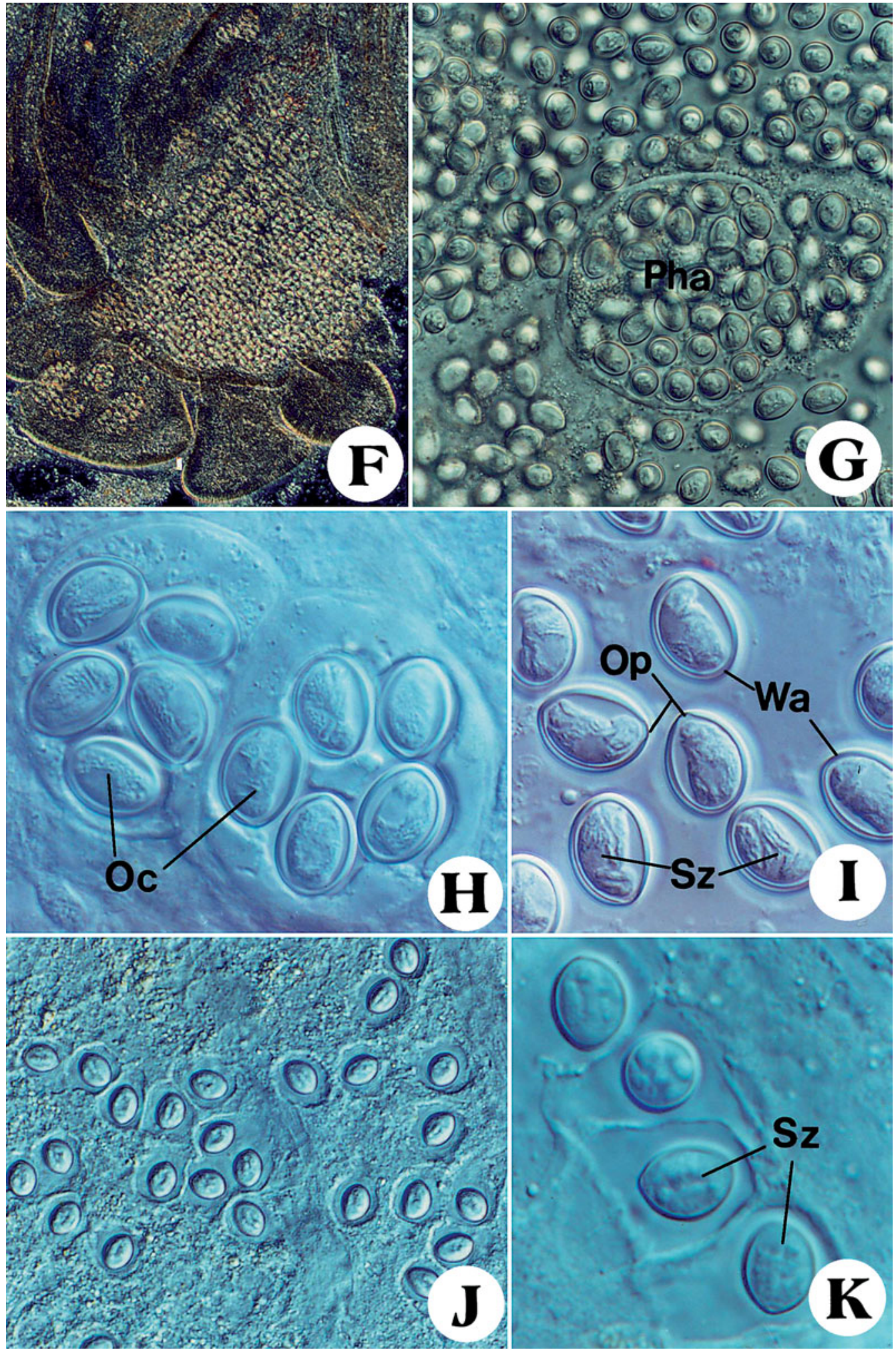

Fig. 4. Nematopsis sp. infecting (A-C) Arcuatula arcuatula, (D-E) Anadara granosa, (F-I) Perna viridis, (J-K) Paphia undulata. (A) Squash preparation of gill tissues showing phagocytes (Pha) $(\times 38.25)$; (B) squash preparation observed by differential interference optics (DIC), showing total of 14 phagocytes (Pha) each containing 5 to 14 oocysts (Oc) $(\times 382.5)$; (C) oocysts formed by wall (Wa), with operculum $(\mathrm{Op})$ and each containing a sporozoite $(\mathrm{Sz})(\times 382.5)$; (D) squash preparation of infected gill observed by DIC, showing 2 phagocytes and a large phagocyte with 11 oocysts (Oc), 4 of which are not in focus plane $(\times 382.5)$; (E) phagocyte containing 21 oocycsts, each of wich contains sporozoite $(\mathrm{Sz})(\times 127.5)$; (F) heavy infection of gill of $P$. viridis $(\times 38.25)$; (G) large phagocyte (Pha) containing 32 oocysts $(\times 382.5)$; (H) 2 small phagocytes, each containing 5 oocysts $(\mathrm{Oc})(\times 977.5)$; (I) oocysts formed by wall (Wa), with operculum $(\mathrm{Op})$, and each containing a sporozoite $(\mathrm{Sz})(\times 977.5)$; $(\mathrm{J})$ squash preparation of infected gill observed by DIC, showing many phagocytes, each containing 1 to 3 oocysts $(\times 382.5)$; (K) 4 oocysts, each containing a sporozoite $($ Sz) $(\times 977.5)$ 
Table 2. Nematopsis sp. Dimensions $(\mu \mathrm{m})$ of oocysts and phagocytes, and number of oocytes per phagocyte in infected bivalve species; mean $\pm \mathrm{SD}$ (range)

\begin{tabular}{|c|c|c|c|c|}
\hline & \multicolumn{2}{|c|}{ Oocysts } & \multirow{2}{*}{$\begin{array}{c}\text { Phagocyte } \\
\text { diameter }\end{array}$} & \multirow{2}{*}{$\begin{array}{c}\text { Oocytes } \\
\text { phagocyte }\end{array}$} \\
\hline & Length & Width & & \\
\hline Arcuatula arcuatula & $16.3 \pm 0.6(14.3-17.4)$ & $12.0 \pm 0.4(10.9-12.6)$ & $93.6 \pm 8.9(81.1-106.8)$ & $3-10$ \\
\hline Anadara granosa & $16.9 \pm 0.7(16.5-18.7)$ & $12.7 \pm 0.3(12.2-13.5)$ & $75.0 \pm 7.1(64.9-86.5)$ & $8-21$ \\
\hline Perna viridis & $17.6 \pm 0.7(16.01-19.1)$ & $12.7 \pm 0.4(12.2-13.9)$ & $60.0 \pm 9.9(47.3-94.6)$ & $8-32$ \\
\hline Paphia undulata & $11.2 \pm 0.6(9.2-12.0)$ & $8.6 \pm 0.5(7.1-9.8)$ & $23.2 \pm 5.7(14.1-27.2)$ & $1-5$ \\
\hline
\end{tabular}

phology of the oocysts are shown in Fig. 4. Table 2 summarizes the sites of the oocysts and phagocytes and the number of oocysts within each phagocyte for each species.

\section{DISCUSSION}

This is the first detailed report of the presence of Nematopsis spp. in bivalves from the Gulf of Thailand. The eugregarine protozoa genus Nematopsis was first described by Schneider (1892), and represents a group of parasites commonly found in marine bivalves and in some marine gastropods (Lauckner 1983). The parasite has also been reported in barnacles (Mavrodiali 1908) and in estuarine crabs (Prasadan \& Janardanan 2001). The first detailed description of a Nematopsis species in commercial bivalves was probably that of N. ostrearum by Prytherch (1938). This author made extensive field observations, and suggested that $N$. ostrearum might have played an important role in oyster mass mortalities along the Atlantic Coast and in the Gulf of Mexico (Prytherch 1940). More recently, interest in Nematopsis spp. has increased due to suggestions that the parasites may play a role in the health of commercial bivalves in Canada (Bower et al. 1992a,b), Portugal (Azevedo \& Cachola 1992), Spain (Navas et al. 1992, Villalba et al. 1993, Soto et al. 1996), Ukraine (Belofastova 1996), Italy (Canestri-Trotti et al. 2000) and Brazil (Azevedo \& Matos 1999). Sprague \& Orr (1955) suggested that heavy infection of the gills or mantle of young bivalves may weaken the juveniles and lead to loss of crop and harvest.

The common Thai practice of feeding marine shrimp with live bivalves could possibly lead to infection and weakening of cultivated shrimp, an example being the extensive cultivation of Penaeus merguensis. This feeding practice is also used in the intensive cultivation of $P$. monodon, whereby shrimp farmers in some areas use live or partially cooked young mussels (Arcuatula arcuatula or Perna viridis) to feed and fatten shrimp prior to harvest. Parasites of the genus Nematopsis have been reported in commercial shrimp species such as Litopenaeus vannamei (Miller et al.
1994). Infection of other commercial crustaceans that are pond-reared, such as the mangrove crab Scylla serrata, may also occur.

Although high infection levels were found in many bivalve species, no oocysts were found in the gill tissues of Donax faba, Meretrix meretrix or Saccostrea cucullata, species that are generally found in the same area as the infected species. This suggests that the degree of infection may be related to habitat type, with heavy infections generally occurring in species living at or near the surface in a muddy substrate or, as in the case of Perna viridis located on bamboo poles in association with many species of fouling organisms.

Gregarines of the genus Nematopsis utilize marine bivalves as normal intermediate hosts (Lauckner 1983). In Thailand, several mass mortalities of commercial bivalves have been reported and attributed to poor environmental conditions, e.g. in the mussel Perna viridis in the Chonburi area, in oysters Saccostrea cucullata from the eastern seaboard provinces of Chantaburi and Trat, and in cockles Anadara granosa of the southern province of Phuket (Pookasawan et al. 1982). The presence of large numbers of phagocytes found in the gill lumen of $P$. viridis in the present study may result in the obstruction of the water-flow between the inhalent and exhalent currents, leading to decreased filtering efficiency and food intake. The tissue damage to the gill through infection observed under light microscopy was, however, not serious.

Our data obtained by monthly sampling revealed some differences in the seasonal prevalence of the parasite in our target bivalves. Prevalence in Donx faba, Meretrix meretrix and Saccostrea cucullata was zero from November 2000 to November 2001; for the other species, however, it was generally high in those months corresponding to the northeast monsoon season (November to February), which is characterized by low surface seawater temperature, high salinity, and low rainfall. The levels of infections decreased during the southwest monsoon season (March to October), which is characterized by higher surface seawater temperature, lower salinity, and high levels of rainfall (Fig. 2). 
Acknowledgements. We thank Dr. Susan Bower for comments, information and suggestions during the initiation of this research. Comments from the reviewers of earlier versions of the manuscript are greatly appreciated. This research was supported in part by a research development grant to Chanawat Tuntiwaranuruk from the Faculty of Science and Graduate Program in Biological Science, Burapha University, Thailand.

\section{LITERATURE CITED}

Azevedo C, Cachola R (1992) Fine structure of the apicomplexa oocyst of Nematopsis sp. of two marine bivalve molluscs. Dis Aquat Org 14:69-73

Azevedo C, Matos E (1999) Description of Nematopsis mytella n.sp. (Apicomplexa), parasite of the mussel Mytella guyanensis (Mytelidae) from the Amazon Estuary and description of its oocysts. Eur J Protistol 35:427-433

Belofastova IP (1996) Gregarines of the genus Nematopsis (Eugregarinida: Porosporidae), parasites of the Black Sea molluscs. Parasitologia 30:159-173

Bower SM, Blackbourn J, Meyer GR (1992a) Parasite and symbiont fauna of Japanese littlenecks, Tapes philippinarum (Adams \& Reeve, 1850), in British Columbia. J Shellfish Res 11:13-19

Bower SM, Blackbourn J, Meyer GR, Nishimura DJH (1992b) Diseases of cultured Japanese scallops (Patinopecten yessoensis) in British Columbia, Canada. Aquaculture 107:201-210

Canestri-Trotti G, Baccarani EM, Paesanti F, Turolla E (2000) Monitoring of infections by protozoa of the genera Nematopsis, Perkinsus, and Porospora in the smooth Venus clam Callista chione from the North-Western Adriatic Sea (Italy). Dis Aquat Org 42:157-161

FAO (Food and Agriculture Organization of the United Nations) (1999) Aquaculture production statistics 1988-1997, FIDI/ C815 (Revision 11), FAO, Rome

Lauckner G (1983) Diseases of Mollusca: Bivalvia. In: Kinne O (ed) Diseases of marine animals, Vol II. Biologische Anstalt Helgoland, Hamburg, p 542-548

Luna LG (1960) Manual of histological staining methods of the Armed Forces Institute of Pathology, 3rd edn. McGraw-Hill, New York

Editorial responsibility: Albert Sparks, Seattle, Washington, USA
Mavrodiali PA (1908) The barnacles of the Black Sea and their gregarine parasites. Preliminary note. Zap Novoross Obshch Estest 32:101-132

Miller DJ, Criollo F, Mora O (1994) A practical diagnostic method for determining intestinal gregarine infection in Penaeus vannamei on a commercial shrimp farm. World Aquacult 25:65-66

Navas JI, Castillo MC, Vera P, Ruiz-Rico M (1992) Principal parasites observed in clams, Ruditapes decussatus (L.), Ruditapes philippinarum (Adams et Reeve), Venerupis pullastra (Montagu) and Venerupis aureus (Gmelin), from the Huelva coast (S.W. Spain). Aquaculture 107: 193-199

Pookasawan T, Boonyarattaplin S, Arirat S, Duongsawad M, Rernpan L (1982) Aquatic diseases. Thai Fish Gaz 40: 41-46 (in Thai)

Prasadan PK, Janardanan KP (2001) Three new species of gregarines (Apicomplexa: Sporozoea: Porosporidae) in the estuarine crabs from Kerala, India. Acta Protozool 40: 303-309

Prytherch HF (1938) Life-cycle of a sporozoan parasite of the oyster. Science 88:451-452

Prytherch HF (1940) The life cycle and morphology of Nematopsis ostrearum sp. nov., a gregarine parasite of the mud crab and oyster. J Morphol 66:39-65

Schneider A (1892) Signalement d'un nouvean sporozoaire. Tabl Zool 2:209-210

Soto M, Pascual S, Rodriguez H, Gestal C, Abollo E, Arias C, Estevez J (1996) Nematopsis spp. Schneider, 1892 (Apicomplexa: Gregarinida) in bivalve molluscs off Ria de Vigo (Galicia, NW Spain). Bull Eur Assoc Fish Pathol 16: $157-160$

Sprague V, Orr PE Jr (1955) Nematopsis ostreum and N. prytherchi (Eugregarina: Porosporidae) with special reference to the host-parasite relations. J Parasitol 41:89-104

Villalba A, Lopez MC, Carballal MJ (1993) Parasites and pathologic conditions of three clam species, Ruditapes decussatus, Venerupis pullastra, and Venerupis rhomboides, in the Galician rias. In: Cervino A, Lomdin A, de-Coo A, Guerra A, Torre M (eds) Proceedings of the 4th National Congress on Aquaculture, Vilanova de Arousa, Galicia, Spain, 21-24 September, 1993. Centro-de-Investigaciones-Marinas, Pontevedra, p 551-556

Submitted: November 10, 2001; Accepted: October 10, 2003 Proofs received from author(s): December 1, 2003 